\title{
KEMAMPUAN KONEKSI MATEMATIK DAN MOTIVASI BELAJAR SISWA DENGAN MENGUNAKAN MODEL PROBLEM-BASED LEARNING (PBL) BERBANTUAN GEOGEBRA DI SMP
}

\author{
Ari Septian ${ }^{1}$, Elsa Komala ${ }^{2}$, \\ ${ }^{1,2}$ Prodi Pendidikan Matematika, Universitas Suryakancana \\ ariseptian@unsur.ac.id \\ elsakomala@gmail.com
}

\begin{abstract}
ABSTRAK
Penelitian ini tentang penggunaan model Problem-Based Learning (PBL) berbantuan Geogebra dalam pembelajaran matematika yang dimaksudkan sebagai salah satu upaya untuk meningkatkan kemampuan koneksi matematik dan motivasi belajar siswa. Subjek pada penelitian ini adalah siswa kelas IX-B SMP Negeri 1 Cianjur. Instrumen yang digunakan adalah tes kemampuan koneksi matematik, angket, dan jurnal. Penelitian ini dilaksanakan sebanyak dua siklus, dimana setiap siklus terdiri dari dua kali pertemuan dan satu tes siklus, setiap siklus terdiri dari 4 kegiatan utama, yaitu perencanaan, tindakan, pengamatan, dan refleksi. Dari hasil penelitian, diperoleh adanya peningkatan rata-rata kemampuan koneksi matematis siswa dari pembelajaran sebelumnya. Ketuntasan belajar secara klasikal telah mencapai ketuntasan belajar yang ideal, yaitu 86,8\% dari jumlah siswa yang telah mencapai ketuntasan belajar. Sementara motivasi belajar siswa pada umumnya positif model Problem-Based Learning (PBL) berbantuan Geogebra dalam pembelajaran matematika. Pembelajaran dengan pendekatan ini membuat siswa lebih mudah memahami materi yang diberikan dan siswa lebih termotivasi untuk belajar matematika.
\end{abstract}

Kata Kunci: Model Problem-Based Learning (PBL), Sofware Geogebra, Kemampuan Koneksi Matematik, Motivasi Belajar.

\section{PENDAHULUAN}

Di era serba digital, upaya menciptakan sumber daya manusia yang handal tentunya diperlukan peningkatan kualitas pendidikan dalam berbagai aspek diantaranya matematika. Matematika merupakan salah satu cabang ilmu pengetahuan yang mempunyai peranan yang sangat besar dalam perkembangan ilmu pengetahuan dan teknologi. Pendidikan matematika juga mempunyai peranan penting dalam membentuk siswa yang dapat berpikir kritis, logis dan sistimatis. Hal tersebut sangat sesuai dengan tiga kompetensi yang dijadikan tolak ukur dalam penilaian di sekolah yaitu kompetensi kognitif, afektif dan psikomotor, didalamnya siswa memiliki kemauan untuk memperoleh pengetahuan, pengembangan jati diri, melaksanakan tugas-tugas tertentu.

Kegunaan pembelajaran matematika di sekolah menurut Ruseffendi (2006: 208), bahwa dengan belajar matematika kita miliki persyaratan untuk bidang studi lain. Dengan 
pembelajaran matematika diharapkan siswa dapat membuat interpretasi fisik dalam arti mampu mengaitkan dan membandingkan fakta matematika dengan kehidupan sehari-hari. Sejalan dengan tujuan kurikuler pengajaran matematika sekolah menengah pertama dan atas menurut Ruseffendi (2006: 206) bahwa siswa harus memiliki keterampilan menyelesaikan soal-soal matematika, baik yang berhubungan dengan kehidupan seharihari, bidang studi lain maupun dalam matematika sendiri. Oleh karena itu siswasangat memerlukan matematika, sehingga dengan mempelajari matematika siswa dapat berprestasi karena sesungguhnya dalam pembelajaran matematika terdapat tujuan yang sangat terkait dengan kehidupan sehari-hari.

Namun dengan melihat fenomena yang terjadi dalam dunia pendidikan kita, belum mampu memperlihatkan hasil yang memuaskan, khususnya pada mata pelajaran matematika. Demikian pula halnya pembelajaran matematika di Sekolah Menengah Pertama, menunjukkan masih dijumpainya kesulitan-kesulitan para siswa dalam mempelajarinya, kondisi ini terjadi juga di SMP Negeri 1 Cianjur. Kondisi hasil belajar siswa untuk mata pelajaran matematika kelas XI-B, semester sebelumnya menunjukkan hasil yang kurang memuaskan, berdasarkan observasi dan wawancara awal terhadap guru matapelajaran matematika hal ini disebabkan siswa belum mampu memaksimalkan kemampuan koneksi antar matematik dan tergolong masih rendah, sehingga dalam penyelesaian soal banyak topik sebelumnya tidak dapat siswa gunakan. Siswa secara individual terisolasi, bekerja sendiri dalam memahami dan menyelesaikan masalah matematika (Davidson, 1990). Sejalan dengan Ruspiani (2000: 70) realita dilapangan kemampuan koneksi matematika siswa tergolong rendah.

Selain itu juga, Bruner (Ruseffendi, 2006: 152) bahwa dalam bidang studi matematika setiap konsep itu berkaitan dengan konsep lain, misalnya antara dalil dengan dalil, antara teori dengan teori, antara topik dengan topik, dan antar cabang matematika (aljabar dan geometri). Sehingga konsep yang baru dipelajari siswa itu harus dikaitkan dengan konsep yang sudah dikenalinya. Selain itu dalam materi matematika siswa kurang merasakan manfaat apa yang diperoleh sehingga cenderung bersifat hafalan saja, yang berdampak sikap siswa cenderung pasif dan kurang motivasi belajar.

Motivasi siswa belajar siswa rendah dapat berdampak pada proses dan hasil belajar yang tidak meningkat dengan baik bahkan menurun. Motivasi memiliki peran penting dalam keberhasilan pembelajaran, siswa yang memiliki motovasi belajar tinggi memiliki 
kemunginan sangat besar untuk berhasil dibandingkan dengan yang tidak memiliki motivasi belajar. Siswa yang memiliki motivasi akan senantiasa berusaha untuk mencapai tujuannya dengan belajar giat, sejalan dengan Mc. Donald (Djamarah, 2011: 18) bahwa motivasi adalah suatu perubahan energi dalam pribadi seseorang yang ditandai dengan timbulna afektif (perasaan) dan reaksi untuk mencapai tujuan.

Untuk menyikapi akibat hasil yang diperoleh dari proses pembelajaran yang berupa akumulasi dari pengetahuan sebelumnya yang satu sama lain terisolasi dan banyaknya siswa mengalami kesulitan dalam mengaplikasikan matematika ke dalam situasi kehidupan real.

Melihat begitu eratnya hubungan koneksi antar topik matematika, matematika dengan bidang lain dan matematika dengan kehidupan sehari-hari tentunya diperlukan model-model mengajar yang dipandang mampu mengatasi kesulitan guru melaksanakan tugas mengajar dan juga tugas belajar siswa. Pada kesempatan ini dengan adanya pelaksanaan Penelitian Dosen di Sekolah, dalam hal ini akan dikaji dengan mencoba menggunakan salah satu alternatif penggunaan model pembelajaran yang dapat merangsang motivasi dan keaktifan siswayaitu model Problem-Based Learning (PBL) berbantuan Geogebra. Model pembelajaran ini menekankan pentingnya pembelajaran yang diawali dengan masalah-masalah yang ditemukan dalam suatu lingkungan sehari-hari. Menurut Arends (2008: 41) PBL merupakan pembelajara yang memiliki esensi yang menyuguhkan berbagai situasi permasalahan yang autentik dan bermakna kepada siswa. Guru tidak hanya memberikan pengetahuan pada siswa, tetapi juga harus membangun pengetahuan dalam pikirannya. Siswa mempunyai kesempatan untuk mendapatkan pengalaman langsung dalam menerapkan ide-ide mereka, ini merupakan kesempatan bagi siswa untuk menemukan dan menerapkan ide-ide mereka sendiri. PBL merupakan lingkungan belajar yang menggunakan masalah untuk belajar, yaitu sebelum siswa mempelajari suatu materi mereka diharuskan mengidentifikasi suatu masalah, baik yang dihadapi secara nyata maupun telaah kasus. Menurut Benoit (2000) masalah yang diajukan sedemikian rupa sehingga siswa menemukan kebutuhan belajar yang diperlukan agar mereka dapat memecahkan masalah tersebut. Sedangkan Geogebra dipergunakan sebagai bantuan bagi guru dalam pembelajaran guna untuk mengantarkan koneksi matematis siswadan mengecek kebenaran dari penyelesaian masalah yang diberikan guru yang dikerjakan oleh siswa. 
Dengan demikian diharapkan dengan model Problem-Based Learning berbantuan Geogebra dapat meningkatkan kemampuan koneksi matematis dan motivasi belajar siswa. Adapun tujuan dari penelitian ini adalah: 1) untuk mengetahui peningkatan kemampuan koneksi matematis siswadengan model Problem Based Learning berbantuan Geogebra; 2) Bagaimana motivasi belajar siswa dengan model Problem Based Learning berbantuan Geogebra dalam pembelajaran matematika.

\section{Model Problem-Based Learning (PBL)}

Herman (Urman, 2010: 28) menyatakan bahwa PBL secara mendasar mengubah pandangan proses dari guna mengajar ke siswa belajar. Hal ini berarti bahwa model PBL dalam pembelajaranmatemaika adalah model pembelajaran yang mempunyai ciri sebagai pembelajaran yang berpusat pada siswa dan guru sebagai fasilitator atau pembimbing sehingga siswa terbiasa dihadapkan dengan maslah-masalah matematik dan melakukan penyelesaian dengan menggunakan kemampuan awal (koneksi) yang dimiliki. Sejalan dengan Abdullah dan Ridwan (2008: 2) bahwa model PBL adalah salah satu model pembelajaran student centred, model ini merupakan model pembelajaran yang menggunakan masalah sebagai langkah awal dalam mengunpulkan dan mengintegrasikan pengetahuan baru. Siswa diberikan permasalahn pada awal pelaksanaan pembelajaran oleh guru, selanjutnya selama pelaksanaan pembelajaran siswa memecahkannya yang akhirnya mengintegrasikan pengetahuan ke dalam bentuk laporan. Suherman (2001) mengungkapkan bahwa model PBL adalah model pembelajaran yang melatih dan mengembangkan kemampuan utnuk menyelesaikan masalah yang berorientasi pada masalah otentik dari kehidupan actual siswa, untuk merangsang kemampuan berfikir tingkat tinggi.

Menurut Subchan, dkk (2018: 35) model PBL mengacu pada: 1) Kurikulum; 2) Responsibility; 3) Realisme; 4) Active-Learning; 5) Umpan balik; 6) Keterampilan umum; 7) Driving Question; 8) Constructive Investigations; 9) Autonomy

Langkah-langkah pelaksanaan PBL menurut Subchan, dkk (2018: 36), sebagai berikut: 
Tabel 1. Langkah-Langkah Model PBL

\begin{tabular}{|c|c|}
\hline Fase & Perilaku Guru \\
\hline $\begin{array}{l}\text { Fase } 1 \\
\text { Mengorientasi siswa pada } \\
\text { masalah }\end{array}$ & $\begin{array}{l}\text { 1. Menjelaskan tujuan pembelajaran, menjelaskan logistik } \\
\text { yang dibutuhkan } \\
\text { 2. Memotivasi siswa untuk terlibat aktif dalam pemecahan } \\
\text { masalah yang dipilih. }\end{array}$ \\
\hline $\begin{array}{l}\text { Fase } 2 \\
\text { Mengorganisasikan siswa }\end{array}$ & $\begin{array}{l}\text { Membantu siswa mendefenisikan dan mengorganisasikan } \\
\text { tugas belajar yang berhubungan dengan masalah tersebut. }\end{array}$ \\
\hline $\begin{array}{l}\text { Fase } 3 \\
\text { Membimbing penyelidikan } \\
\text { individual dan kelompok }\end{array}$ & $\begin{array}{l}\text { Mendorong siswa untuk mengumpulkan informasi yang } \\
\text { sesuai, melaksanakan eksperimen untuk mendapatkan } \\
\text { penjelasan dan pemecahan masalah }\end{array}$ \\
\hline $\begin{array}{l}\text { Fase } 4 \\
\text { Mengembangkan dan } \\
\text { menyajikan hasil karya }\end{array}$ & $\begin{array}{l}\text { Membantu siswa dalam merencanakan dan menyiapkan } \\
\text { karya yang sesuai seperti laporan, model dan berbagi tugas } \\
\text { dengan teman }\end{array}$ \\
\hline $\begin{array}{lr}\text { Fase } 5 & \\
\text { Menganalisa } & \text { dan } \\
\text { mengevaluasi } & \text { proses } \\
\text { pemecahan masalah } & \end{array}$ & $\begin{array}{l}\text { Mengevaluasi hasil belajar tetang materi yang telah } \\
\text { dipelajari/meminta kelompok presentasi hasil kerja }\end{array}$ \\
\hline
\end{tabular}

\section{Program Geogebra}

Menurut Kusumah (2003), berbagai manfaat program komputer dalam pembelajaran matematika yakni: program-program komputer sangat ideal untuk dimanfaatkan dalam pembelajaran konsep-konsep matematika yang menuntut ketelitian tinggi, konsep atau prinsip yang repetitif, penyelesaian grafik secara tepat, cepat, dan akurat.

Geogebra merupakan salah satu program komputer yang dapat dimanfaatkan sebagai media pembelajaran matematika dan dikembangkan oleh Markus Hohenwarter pada tahun 2001. Menurut Hohenwarter (2008), Geogebra adalah program komputer untuk membelajarkan matematika khususnya geometri dan aljabar. Geogebra dapat diinstal pada komputer pribadi dan dimanfaatkan kapan dan di manapun oleh siswa maupun guru. Bagi guru, Geogebra menawarkan kesempatan yang efektif untuk mengkreasi lingkungan belajar online interaktif yang memungkinkan siswa mengeksplorasi berbagai konsepkonsep matematis.

Program Geogebra sangat bermanfaat bagi guru maupun siswa. Beberapa pemanfaatan program Geogebra dalam pembelajaran matematika menurut Hohenwarter (2008) adalah sebagai berikut: 1) dapat menghasilkan lukisan-lukisan geometri dengan cepat dan teliti dibandingkan dengan menggunakan pensil, penggaris, atau jangka; 2) 
adanya fasilitas animasi dan gerakan-gerakan manipulasi (dragging); 3) program Geogebra dapat memberikan pengalaman visual yang lebih jelas kepada siswa dalam memahami konsep, khususnya konsep perbandingan trigonometri pada segitiga siku-siku; 4) dapat dimanfaatkan sebagai balikan/ evaluasi untuk memastikan bahwa lukisan yang telah dibuat benar; 5) mempermudah guru/ siswa untuk menyelidiki atau menunjukkan sifat-sifat yang berlaku pada suatu objek geometri; 6) Geogebra memberi kemudahan bagi guru dan siswa untuk mengeksplorasi berbagai bentuk dan konsep matematika.

\section{Kemampuan Koneksi Matematik}

Koneksi matematik merupakan dua kata berasal dari bahasa inggris yaitu mathematical connection, yang dipopulerkan oleh NCTM dan dijadikan sebagai standar kurikulum pembelajaran matematika sekolah dasar dan menengah. Persepsi bahwa konsep-konsep matematika merupakan konsep-konsep yang saling berkaitan haruslah meresap dalam pembelajaran matematika di sekolah. Jika persepsi ini sebagai landasan guru dalam pembelajaran matematika maka setiap mengkaji meteri selalu mengkaitkan dengan materi lain dan kehidupan sehari-hari.

Membuat koneksi merupakan cara untuk menciptakan pemahaman dan sebaliknya memahami sesuatu berarti membuat koneksi, menurut Michener (Ruspiani, 2000: 21). Untuk memahami suatu objek secara mendalam seseorang harus mengetahui: (1) obyek itu sendiri; (2) relasinya dengan obyek lain yang sejenis; (3) relasi dengan obyek lain yang tak sejenis; (4) relasi dual dengan obyek lainnya yang sejenis; (5) relasi dengan obyek dalam teori lainnya.

Menurut NCTM (Ruspiani, 2000: 8) terdapat tiga tujuan koneksi matematik di sekolah, yaitu: Pertama, memperluas wawasan pengetahuan siswa. Dengan koneksi matematika siswa, diberikan suatu materi yang bisa menjangkau ke berbagai aspek permasalahan baik di dalam maupun di luar sekolah, sehingga pengetahuan yang dipeoleh siswa tidak bertumpu pada materi yang sedang dipelajari saja. Kedua, memandang matematika sebagai suatu keseluruhan yang padu bukan sebagai materi yang berdiri sendiri. Secara umum, materi matematika terdiri atas aljabar, geometri, trigonometri, aritmatika, kalkulus dan ststistika dengan masing-masing materi atau topik yang ada di dalamnya. Masing-masing topik tersebut bisa dilibatkan atau terlibat dengan topik yang lainnnya. Ketiga, menyatakan relevansi dan manfaat baik di sekolah maupun di luar 
sekolah. Melalui koneksi matematik, siswa diajrakan konsep dan ketrampilan dalam memecahkan masalah dari berbagai bidang yang relevan, baik dengan bidang matematika itu sendiri maupun dengan bidang di luar matematika.

Tujuan koneksi matematik adalah siswa dapat memandang matematika sebagai suatu kesatuan yang utuh, menyelidiki masalah dan menggambarkan hasil-hasil dari menggunakan materi matematka atau mempresentasikannya, memahami ide matematika untuk memahami ide matematika selanjutnya, menggunakan pikiran matematika dan membuat model dalam memecahkan masalah dalam disiplin ilmu lain.

\section{Motivasi Belajar}

Salah satu aspek psikologi yang ada pada diri siswa adalah motivasi. Motivasi merupakan suatu proses yang menentukan tingkatan kegiatan, intensitas, konsisten serta arah umum dari tingkah laku manusia Egsenck (Slameto, 2003: 170). Begitupun pada kegiatan belajar mengajar siswa juga memerlukan motivasi. Motivasi belajar menurut Sardiman (2012) terdiri dari: 1) motivasi intrinsik adalah motivasi yang menjadi aktif atau berfungsinya tidak perlu ada perangsang dari luar, karena dalam diri setiap individu sudah ada dorongan untuk melakukan sesuatu; 2) motivasi ekstrinsik adalah motif yang aktif dan berfungsi karena adanya dorongan atau rangsanagan dari luar. Dalam motivasi belajar siswa berada di tangan para guru, orang tua dan masyarakat yang lain.

Dimyati \& Mudjiono (1994: 89) mengungkapkan bahwa unsur-unsur yang mempengaruhi motivasi belajar adalah cita-cita atau aspirasi siswa, motivasi belajar tampak pada keinginan anak sejak kecil. Dalam pembelajaran, kemandirian, keinginan yang terpuaskan dapat memperbesar kemauan dan semangat belajar bahkan dalam proses kegiatan pembelajaran di kelas penguatan dengan hadiah atau juga hukuman akan dapat mengubah keninginan menjadi kamuan dan kemudian menjadi cita-cita.

\section{METODE PENELITIAN}

Penelitian ini merupakan Penelitian Tindakan Kelas (classroom action research) yang berusaha mengkaji dan merefleksi secara kolaboratif suatu alternatif pembelajaran. Penelitian yang dilakukan terdiri dari dua siklus, dimana setiap siklus atau tindakan terdiri dari empat tahap, yaitu: (1) Perencanaan (planning); (2) Tindakan (acting); (3) Pengamatan (observing); dan (4) Refleksi (reflecting). Tahap-tahap penelitian dalam masing-masing tindakan terjadi secara berulang yang akhirnya menghasilkan beberapa tindakan dalam 
penelitian tindakan kelas. Populasi penelitian ini adalah siswa kelas IX-B SMP Negeri 1 Cianjur semester ganjil tahun ajaran 2018/2019.

Untuk mengukur peningkatan kemampuan koneksi matematik digunkana tes yang dilakukan di akhir siklus dalam bentuk soal uraian. Materi yang diujikan adalah materi pada pkok bahsan Perpangkatan dan Bentuk Akar. Dari tes dianalisis dan dibuat kategori jawaban. Untuk mengetahui keberhasilan penelitian tindakan ini adalah daya serap klasikal (DSK). Suatu kelas disebut tuntas belajarnya bila kelas tersebut telah mencapai 85\% siswa mencapai daya serap $\geq$ Kriteria Ketuntasan Minimal sekolah yaitu 75 .

Angket siswa diberikan di akhir siklus berupa lembar pernyataan bertujuan untuk mengetahui motivasi belajar siswa terhadap pembelajaran matematika dengan model Problem-Based Learning berbantuan Geogebra. Angket menggunakan pernyataan yang berisi jawaban "iya" dan "tidak". Angket dibuat sebanyak 10 pernyataan positif.

Lembar observasi yang digunakan untuk mengetahui aktifitas siswa selama proses pembelajaran berupa pertanyaan urian diberikan bertujuan untuk mengetahui sejauh mana sikap siswa terhadap pembelajaran matematika yang diberikan dalam upaya perbaikan pada siklus berikutnya yang dilakukan oleh guru matematika pada kelas tersebut.

\section{HASIL DAN PEMBAHASAN}

Penelitian tindakan kelas ini diawali dengan hasil orientasi lapangan dan observasi awal (pra tindakan) selama dua kali pertemuan, kemudian diadakan refleksi untuk meningkatkan proses pembelajaran. Dari hasil refleksi kemudian dilakukan tindakan pembelajaran dengan menggunakan model PBL berbantuan Geogebra. Kemudian setelah dilakukan analisis terhadap hasil awal tersebut, penelitian ini dilaksanakan melalui siklus yang berdaur serta berkelanjutan dan dilaksanakan dalam dua siklus.

\section{Hasil Tindakan Pembelajaran Siklus I}

Peneliti dalam hal ini dosen berkolaborasi dengan guru matapelajaran matematika mempersiapkan perangkat pembelajaran yang diperlukan dalam proses belajar mengajar diantaranya merancang RPP, dan Lembar Kerja Siswa, membuat soal tes beserta kisikisinya. RPP berisi tentang skenario pembelajaran yang harus dilaksanakan dalam pembelajaran agar indikator pembelajaran yang telah ditetapkan dapat dicapai.

Pembelajaran pada siklus I pertemuan pertama dilaksanakan pada hari Rabu 08 Agustus 2018, pukul 07.10-08.30, dengan materi pembelajaran Bilangan berpangkat, 
Perkalian pada perpangkatan, Pembagian pada perpangkatan. Pertemuan kedua, Senin 20 Agustus 2018 pukul 12.10-15.10 dengan materi Pangkat Nol, Pangkat negarif. Pertemuan ketiga, Selasa 21 Agustus 2018, pukul 07.10-08.30 guru memberikan tes untuk mengetahui kemampuan koneksi matematik siswa pada siklus I.

Proses pembelajaran pada fase 1 mengorientasi siswa kepada masalah, peneliti mengawali dengan memberikan salam, memeriksa kehadiran siswa, menyampaikan tujuan pembelajaran, prosedur model PBL benrbantuan Geogebra serta memberikan motivasi dan apersepsi untuk mendorong siswa agar dapat berpartisipasi aktif mengikuti pembelajaran yang dilaksanakan.

Pada langkah selanjutnya fase 2 mengorganisasikan siswa, peneliti memberikan gambaran umum tentang materi dengan membawa situasi sehari-hari kedalam lingkungan belajara. Setelah materi disampaikan siswa didistribusikan pada kelompok yang telah ditentukan secara heterogen lalu dibagikan LKS pada tiap kelompok untuk diselesaikan dalam kelompok masing-masing. Pada fase 3 membimbing penyelidikan individu dan kelompok, yakni selama diskusi berlangsung peneliti berkeliling mengamati aktivitas siswa dan bertindak sebagai motivator dan fasilitator membimbing dan mengarahkan siswa jika ada kesulitan.

Pada pertemuan pertama siswa kurang antusias mengerjakan tugas-tugas yang terdapat dalam LKS. Hal ini dapat dilihat dari aktivitas mereka yang sebagian masih tidak serius dalam belajar dengan model yang peneliti lakukan karena siswa memerlukan penyesuaian karena selama ini dalam proses pembelajaran mereka hanya menggunakan secara langsung rumus-rumus tanpa memahami terlebih dahulu mengapa rumus yang mereka pergunakan bisa seperti itu. Pada pertemuan II siswa terlihat lebih antusias mengerjakan tugas-tugas yang terdapat dalam LKS. Hal ini dapat dilihat dari aktivitas mereka lebih aktif dari pembelajaran yang sebelumnya

Pada kegiatan selanjutnya, fase 4 mengembangkan dan menyajikan hasil karya pada awalnya hanya satu dua kelompok yang berani maju untuk mempresentasikan hasil kerjanya, hal ini disebabkan karena mereka masih merasa canggung dan takut salah menjawab jika ada pertanyaan dari teman-temannya dari kelompok yang lain. Kegiatan untuk membahas LKS belum optimal karena waktu yang terbatas siswa belum terbiasa dengan batasan waktu yang diberikan oleh peneliti selama mengerjaka permasalahn yang terdapat pada LKS. Setelah diskusi selesai, fase 5 menganalisa dan mengevaluasi proses penyelesaian masalah, peneliti mengumumkan kelompok yang terbaik dan memberikan penghargaan kepada kelompok tersebut, kemudian peneliti bersama siswa menyimpulkan 
materi yang telah dipelajari. Kemudian guru memberikan latihan soal kepada siswa untuk mengetahui apakah siswa dapat menggunakan rumus-rumus yang telah ditemukan dalam berbagai macam soal.

Tabel 2. Refleksi Tindakan Pembelajaran Siklus I

\begin{tabular}{|c|c|c|}
\hline $\begin{array}{c}\text { Kendala/ Kesulitan } \\
\text { Peneliti }\end{array}$ & Catatan Lapangan & Saran Pe \\
\hline $\begin{array}{l}\text { 1. Memotivasi siswa } \\
\text { untuk lebih aktif } \\
\text { mengemukakan } \\
\text { ide-idenya dalam } \\
\text { diskusi kelompok. } \\
\text { 2. Mengefektifkan } \\
\text { dan dalam } \\
\text { mengalokasikan } \\
\text { waktu kelompok } \\
\text { diskusi kersedia } \\
\text { yang te } \\
\text { dengan baik. }\end{array}$ & $\begin{array}{l}\text { 1. Sebagian besar siswa masih } \\
\text { bergantung pada peneliti } \\
\text { untuk memahami materi. } \\
\text { 2. Pengamatan dan bimbingan } \\
\text { yang dilakukan oleh guru } \\
\text { belum merata, dengan } \\
\text { kondisi siswa yang termasuk } \\
\text { kelas gemuk. } \\
\text { 3. Masih terdapat siswayang } \\
\text { tidak serius selama } \\
\text { pembelajaran. } \\
\text { 4. Sebagian kelompok belum } \\
\text { berani menyajikan hasil } \\
\text { diskusi di depan kelas. }\end{array}$ & $\begin{array}{l}\text { 1. Peneliti melatih siswa untuk } \\
\text { berfikir dan belajar mandiri } \\
\text { sehingga siswa lebih aktif dan } \\
\text { peneliti hanya berperan } \\
\text { sebagai fasilitator dan } \\
\text { motivator. } \\
\text { 2. Peneliti harus lebih } \\
\text { memotivasi siswa untuk lebih } \\
\text { aktif mengemukakan ide- } \\
\text { idenya, berdiskusi dan } \\
\text { menyajikan hasil pekerjaannya } \\
\text { di depan kelas. } \\
\text { 3. Peneliti melakukan } \\
\text { pengamatan dan bimbingan } \\
\text { secara merata di kelas. }\end{array}$ \\
\hline
\end{tabular}

\section{Hasil Tindakan Pembelajaran Siklus II}

Tahapan-tahapan pada siklus II ini sama dengan tahapan-tahapan yang terdapat pada siklus I. Pembelajaran pertemuan 1 siklus II dilaksanakan pada hari Senin 21 Agustus 2018 pukul 12.10-15.10 dengan materi Bentuk Akar. Pertemuan kedua, Selasa 04 September 2018 pukul 07.10-08.30 dengan materi Notasi Ilmiah. Pertemuan ke 3, Senin 10 September 2018 pukul 12.10-13.10 tes untuk mengetahui kemampuan koneksi matematik siswa pada siklus II yang merupakan pertemuan terakhir dari seluruh rangkaian tindakan penelitian kelas ini.

Pada siklus ini siswa sudah mulai bisa beradaptasi dan terbiasa dengan model pembelajaran yang dilaksanakan sehingga siswa sangat antusias melakukan diskusi dalam kelompok mereka masing-masing, karena semua ingin menjadi pemenang agar bisa mendapatkan penghargaan. Para siswa banyak yang mengajukan pertanyaan kepada peneliti. Peneliti secara bergilir memberikan bimbingan kepada tiap-tiap kelompok. Peneliti meminta salah satu kelompok yang belum pernah presentasi untuk maju 
mempresentasikan hasil diskusi kelompoknya di depan kelas. Kemudian peneliti memeriksa hasil kerjadari kelompok lain dan peneliti memberikan kesempatan kepada kelompok laiuntuk menanggapi apabila memiliki jawaban berbeda.

Tabel 3. Refleksi Tindakan Pembelajaran Siklus II

\begin{tabular}{lll}
\hline $\begin{array}{c}\text { Kendala/ Kesulitan } \\
\text { Peneliti }\end{array}$ & Catatan Lapangan & \multicolumn{1}{c}{ Saran Perbaikan } \\
\hline $\begin{array}{l}\text { Mengefektifkan dan } \\
\text { mengalokasikan } \\
\text { waktu siswa ketika } \\
\text { diskusi kelompok yang } \\
\text { tersedia dengan baik. }\end{array}$ & $\begin{array}{l}\text { 1. Pada saat diskusi } \\
\text { berlangsung masih } \\
\text { ada siswa yang } \\
\text { ngobrol dan ribut. }\end{array}$ & $\begin{array}{l}\text { 1. } \\
\text { Disarankan pada peneliti selanjutnya } \\
\text { agar mampu membiasakan siswa } \\
\text { dalam penggunaan waktu saat diskusi } \\
\text { kelompok dengan maksimal sesuai } \\
\text { yang tersedia dengan baik. }\end{array}$ \\
& $\begin{array}{l}\text { 2. Tindakan pada } \\
\text { siklus II tuntas } \\
\text { secara menyeluruh }\end{array}$ & $\begin{array}{l}\text { 2. Peneliti dalam pemberian bimbingan } \\
\text { secara merata terkhusus bagi kelas } \\
\text { gemuk (jumlah siswa dalam satu kelas } \\
\text { yang banyak) }\end{array}$ \\
& &
\end{tabular}

Dari data hasil tes pada setiap akhir tindakan pembelajaran untuk mengetahui keberhasilan penelitian dan kontribusi pembelajaran matematika dengan menggunakan model PBL berbantuan Geogebra terhadap kemampuan koneksi matematik dan motivasi belajar siswa untuk tiap siklus.

Tabel 4. Ketuntasan Belajar Siswa

\begin{tabular}{ccc}
\hline Siklus & I & II \\
\hline Daya Serap Klasikal (\%) & $60,5 \%$ & $86,8 \%$ \\
\hline Rata-Rata Skor Tes & 58,5 & 71,3 \\
\hline Tuntas & 23 siswa & 33 siswa \\
\hline Tidak tuntas & 15 siswa & 5 siswa \\
\hline Maksimum & 80 & 90 \\
\hline Minimum & 0 & 0 \\
\hline
\end{tabular}

Ketuntasan belajar yang disajikan dalam tabel 3 memperlihatkan bahwa pada siklus I, DSK belum mencapai $85 \%$ yaitu hanya sebesar 60,5\%, sedangkan DSK pada siklus II mencapai $86,8 \%$, sehingga pada siklus II kelas tersebut telah tuntas belajarnya. Hal ini menunjukkan bahwa dengan menggunakan model PBL berbantuan Geogebra menyebabkan kelas tersebut telah tuntas belajarnya karena pada tes siklus II kelas telah mencapai 85\% siswa yang mencapai $\geq$ KKM sekolah yaitu 75 .

Dari data angket siswa bahwa sebanyak 29 siswadengan persentase sebesar 76,3\% mempunyai motivasi belajar yang positif dan 9 siswa yakni 23,7\% mempunyai motivasi 
belajar yang negatif terhadap pembelajaran matematika dengan model PBL berbantuan Geobegra.

Tabel 5. Data Hasil Angket Siswa

\begin{tabular}{cccc}
\hline No & Sifat Pernyataan & $\begin{array}{c}\text { Jumlah } \\
\text { Siswa }\end{array}$ & \% \\
\hline 1. & Positif & 29 & 76,3 \\
\hline 2. & Negatif & 9 & 23,7
\end{tabular}

Berdasarkan data pada tabel 5, terdapat dua sifat pernyataan, yaitu positif dan negatif. Meskipun masih ada siswa yang memberikan respon negatif tetapi pada umumnya siswamemberikan respon yang positif. Dengan model PBL berbantuan Geogebra pada pembelajaran matematika maka motivasi belajar siswa diciptakan suatu kondisi tertentu sehingga siswa tergerak untuk belajar. Faktor yang mempengaruhi motivasi belajar tersebut yakni faktor dalam diri siswa dan dari luar misalnya keluarga, lingkungan sekolah, masyarakat terutama guru. Model pembelajaran, yang dilakukan guru sangat berpengaruh terhadap motivasi belajar siswa dalam pembelajaran matematika.

\section{KESIMPULAN}

1. Model Problem-Based Learning berbantuan Geogebra dapat meningkatkan kemampuan koneksi matematik siswa. Dilihat dari segi ketuntasan belajar siswasecara klasikal sudah mencapai ketuntasan belajar yang ideal yaitu $86,8 \%$ dari jumlah siswa, dan rata-rata skor tes yang diperoleh siswa mengalami peningkatan untuk setiap tindakan pembelajaran.

2. Motivasi belajar siswa terhadap model Problem-Based Learning berbantuan Geogebra dalam pembelajaran matematika pada umumnya positif.

\section{REFERENSI}

Abdullah, A.G. \& Ridwan, T. (2008). Implementasi Problem Based Learning PBL pada Proses Pembelajaran di BPTP Bandung. Jurnal Penelitian Pendidikan. 5, (13), 110.

Arends, Richard. I. (2008). Belajar untuk Mengajar.Edisi ke tujuh alih bahasa oleh Helly Prayitno dan Sri Mulyantani Prayitnodari judul Learning to Teach. Seven edition. Yogyakarta: Pustaka Pelajar. 
Benoit, Bob. (2000). Problem Based Learning. Diakses: www.pbli.org/pbl/pb15. Online: 12 September 2015.

Davidson, N. (1990). "Small Group Cooperative Learningin Mathematics". Dalam Teaching and Learning Mathematics in the 1990s. Yearbook. Reston, Virginia: NCTM.

Dimyati \& Mudjiono. (1994). Belajar dan Pembelajaran. Jakarta: Depdikbud.

Djamarah, S. B. (2011). Psikologi Belajar. Jakarta: Rineka Cipta.

Hohenwarter, M., et al. (2008). Teaching and Learning Calculus with Free Dynamic Mathematics

Tersedia:

http://www.publications.uni.lu/record/2718/files/ICME11-TSG16.pdf. Nopember 2015] .

Kusumah, Yaya S. (2003). Desain dan Pengembangan Bahan Ajar Matematika Interaktif Berbasiskan Teknologi Komputer. Makalah terdapat pada Seminar Proceeding Nasional Seminar on Science and Math Education. FMIPA UPI Bandung Kerjasama dengan JICA.

Ruseffendi. (2006). Pengantar Kepada Membantu Guru Mengembangkan Kompetensinya dalam Mengajarkan Matematika untuk Meningkatkan CBSA. Bandung: Tarsito.

Ruspiani. (2000). Kemampuan untuk Melakukan Koneksi. Tesis UPI Bandung: Tidak diterbitkan.

Sardirman, A. M. (2012). Interaksi \& Motivasi Belajar Mengajar. Cetakan ke-21. Jakarta: Rajawali Pers.

Slameto. (2003). Belajar dan Faktor-Faktor yang Mempengaruhinya. Jakarta: Rineka Cipta.

Subhan, dkk. (2018). Buku Guru Matematika SMP/ MTs Kelas IX Kurikulum 2013 Edisi Revisi 2018. Jakarta: Kemendikbud.

Suherman, Dkk. (2001) Strategi Pembelajaran Kontemporer. Bandung: JICA.

Urman (2010). Pembelajaran Berbasis Masalah Terstruktur Untuk Meningkatkan Kemampuan Penalaran Matematik Siswa Sekolah Menengah Pertama Tesis UPI Bandung: Tidak Diterbitkan. 